\title{
METAFORA VISUAL PADA IKLAN OBAT ANTISEPTIK VIDISEP Kajian Semiotika
}

\author{
Riki Himawan \\ (Email: kicuy.riki@gmail.com) \\ Program Studi Desain Komunikasi Visual \\ Fakultas Seni Rupa dan Desain \\ Universitas Kristen Maranatha \\ JI. Suria Sumantri, MPH no. 65, Bandung, Indonesia \\ Agung Budi Waspada \\ (email : agungebw.nalardiagonal@gmail.com) \\ Program Studi Desain Komunikasi Visual \\ Fakultas Seni Rupa dan Desain \\ Institut Teknologi Bandung \\ JI. Ganesha No. 10. Lb Siliwangi, Kecamatan Coblong, Kota Bandung, Indonesia
}

\begin{abstract}
ABSTRAK
Salah satu cara yang biasa digunakan untuk menambah daya tarik sebuah iklan adalah dengan memakai pendekatan metafora visual. Iklan obat antiseptik Vidisep adalah salah satu iklan yang menggunakan pendekatan metafora visual. Iklan Vidisep meraih penghargaan tertinggi kategori iklan media cetak dalam Citra Pariwara tahun 2016. Sehingga sebagai sebuah karya visual, iklan ini dianggap telah memenuhi persyaratan dari segi kreativitas dalam visualisasinya. Pemakaian metafora visual menandakan bahwa iklan ini mengedepankan bahasa tanda dalam penyampaian pesannya. Penelitian kualitatif dengan penggambaran secara deskriptif bertujuan untuk menelaah struktur tanda dan pesan pada iklan yang memakai pendekatan metafora visual. Melalui analisis semiotika Roland Barthes menunjukkan bahwa iklan obat antiseptik Vidisep memakai bahasa tanda yang disesuaikan dengan karakteristik dan fungsi obat antiseptik. Pemaknaan pada visualisasi iklan didukung oleh penyimpangan berseni (artful deviation) yang mampu mendukung terbentuknya metafora visual sebagai sebuah strategi persuasi dalam iklan ini.
\end{abstract}

Kata Kunci: iklan; retorika visual; metafora visual; semiotika

\section{ABSTRACT}

One of the ways commonly used to increase the appeal of an advertisement is to use a visual metaphor approach. Vidisep antiseptic drug advertisement is an advertisement that uses a visual metaphor approach. Vidisep's ad won the highest award in the print media advertising category in Citra Pariwara in 2016. So as a visual work, this ad is considered to have met the requirements in terms of creativity in its visualization. The use of visual metaphors indicates that this advertisement puts forward the language of signs in conveying its message. Qualitative research with descriptive 
depiction aims to examine the structure of signs and messages in advertisements using a visual metaphor approach. Through Roland Barthes' semiotic analysis, it is shown that the antiseptic drug advertisement for Vidisep uses a sign language that is adjusted to the characteristics and function of the antiseptic drug. The meaning of advertising visualization is supported by artful deviation which is able to support the formation of visual metaphors as a persuasion strategy in this advertisement.

Keywords: advertisement; visual rhetoric; visual metaphor; semiotics 


\section{PENDAHULUAN}

Iklan merupakan sebuah bentuk komunikasi promosi melalui media massa maupun media interaktif yang ditujukan untuk khalayak sasaran yang telah ditentukan. Menurut Philip Kotler, iklan adalah segala bentuk presentasi nonpersonal dan promosi suatu ide, barang, atau jasa yang dibayar oleh sponsor yang dapat diidentifikasi (Kotler dan Amstrong, 2018). Periklanan adalah sebuah bentuk komunikasi persuasif yang memanfaatkan media massa dan interaktif untuk mencapai khalayaknya dalam upaya menghubungkan pihak sponsor dengan pembelinya, menyediakan informasi tentang produk, dan menafsirkan fitur produk dalam kaitannya dengan kebutuhan dan keinginan pelanggan (Moriarty dkk, 2015).

Berbagai upaya dilakukan pihak perusahaan produsen agar iklan produk atau jasa yang mereka tawarkan bisa menarik respons konsumennya. Forceville (2002) menyatakan bahwa pengiklan harus berusaha agar iklannya diperhatikan di antara berbagai iklan lain, dan kemudian menciptakan dampak yang efektif secara maksimal selama rentang waktu singkat ketika berhasil menarik perhatian konsumen. Daya tarik iklan menurut Moriarty dkk. (2011) adalah sesuatu yang menggerakkan orang, berbicara tentang keinginan atau kebutuhan mereka, dan menggairahkan minat mereka. Sehingga dapat dipahami bahwa daya tarik iklan dipakai untuk menarik perhatian konsumen atau mempengaruhi perasaan mereka terhadap produk atau jasa yang ditawarkan.

Pemakaian retorika visual adalah salah satu cara untuk menarik perhatian konsumen dengan memakai pendekatan daya tarik emosional. Daya tarik emosional adalah daya tarik yang terkait dengan pemenuhan kebutuhan sosial dan psikologi konsumen dalam pembelian suatu produk tertentu (Morissan, 2010). Fenomena pemakaian retorika visual menjadi sesuatu yang lazim ditemui dalam iklan. Retorika visual akan menghasilkan karya visual yang menghibur dan tidak mudah dilupakan karena menimbulkan kedekatan secara emosional. 
Jenis retorika visual yang sering dipakai dalam iklan adalah metafora visual. Pendekatan iklan dengan pemakaian metafora visual lebih mengedepankan unsur persuasi dalam penyampaian pesannya. Melalui cara ini khalayak sasaran merasa yakin terhadap kebenaran gagasan yang terdapat dalam pesan iklan yang mereka tangkap melalui indera visual mereka. Sehingga pemilihan aset benda-benda yang ada pada iklan adalah suatu representasi yang digambarkan secara simbolik dan merupakan bujukan halus produsen agar konsumen mau membeli produk yang ditawarkan (Nurusholih, 2019).

Sebagai objek penelitian mengenai respons konsumen terhadap iklan ini adalah iklan obat antiseptik Vidisep. Iklan Vidisep meraih penghargaan tertinggi kategori iklan media cetak dalam Citra Pariwara tahun 2016 (www.citrapariwara.org). Citra Pariwara merupakan sebuah ajang lomba kreativitas insan periklanan Indonesia. Kegiatan tahunan ini diselenggarakan oleh Persatuan Perusahaan Periklanan Indonesia (P3I). Berbagai iklan yang mengikuti acara ini merupakan karya-karya terbaik yang mewakili biro iklan maupun pribadi. Sehingga dapat dikatakan bahwa iklan Vidisep dianggap telah memenuhi persyaratan dari segi kreativitas dalam visualisasinya.

Penelitian yang dilakukan terhadap iklan media cetak Vidisep ditujukan untuk menelaah struktur tanda dan pesan yang dipergunakan untuk mempersuasi khalayaknya. Iklan ini akan dianalisis secara semiotika melalui teori Roland Barthes sehingga akan diketahui relasi antara karakteristik dan fungsi obat antiseptik Vidisep dengan visualisasi yang memakai pendekatan metafora visual.

\section{METODE PENELITIAN}

Metode penelitian yang digunakan adalah metode penelitian kualitatif. Pendekatan yang dilakukan untuk mengungkap struktur tanda pada iklan yang memakai metafora visual ini dengan melalui pendekatan semiotika. Teori semiotika Roland Barthes dipilih untuk mengetahui makna yang terdapat pada visualisasi iklan. Penggambaran secara deskriptif 
akan mengungkap makna denotatif, konotatif, dan mitos pada visual iklan Vidisep.

Tahapan pengumpulan data yang dilakukan adalah sebagai berikut :

- Studi literatur, dilakukan untuk memahami teori-teori yang berhubungan dengan penelitian.

- Dokumentasi, dilakukan dengan cara mencari visualisasi iklan-iklan peserta Citra Pariwara, khususnya yang memakai pendekatan metafora visual, untuk menjadi objek studi kasus.

- Kuesioner secara online, dengan tujuan untuk menentukan sebuah iklan yang akan menjadi objek penelitian.

Penentuan objek penelitian dilakukan melalui beberapa tahapan. Tahap pertama adalah dengan melakukan proses dokumentasi terhadap iklan-iklan yang menjadi pemenang Citra Pariwara dari tahun 2015 sampai tahun 2019. Kemudian dilakukan pemilihan terhadap iklan yang memakai pendekatan metafora visual. Penentuan iklan yang memakai metafora visual didasarkan pada teori yang dicetuskan Stuart Kaplan (Smith dkk., 2005). Menurut Kaplan sebuah iklan yang memakai metafora visual harus memperlihatkan kehadiran metafora, terpenuhinya dua syarat metafora, serta teridentifikasinya sifat-sifat yang ditransfer.

Kemudian iklan-iklan yang telah diidentifikasi memakai pendekatan retorika visual ini diperlihatkan kepada 100 orang responden. Mereka adalah mahasiswa yang berasal dari tiga universitas yang berbeda di kota Bandung. Penentuan tiga universitas ini adalah untuk meningkatkan validitas data penelitian melalui teknik triangulasi sumber atau sering juga disebut triangulasi data.

Iklan yang terpilih adalah iklan yang paling disukai oleh responden. Dalam penelitian yang telah dilakukan, iklan Vidisep menjadi iklan yang paling disukai oleh mereka (55\%). Menarik untuk diteliti bagaimana struktur tanda pada iklan ini bisa menyampaikan pesannya dan ditampilkan melalui metafora visual sehingga mampu menarik perhatian responden. 
Analisis terhadap pemaknaan yang terjadi pada iklan Vidisep dilakukan melalui dua tahapan. Tahapan pertama adalah mendeskripsikan syarat-syarat yang telah dipenuhi iklan ini sehingga memenuhi syarat sebagai iklan metafora visual. Teori Stuart Kaplan merupakan teori yang akan dipakai untuk analisis tahap ini. Pendeskripsian makna visual yang dibentuk secara kreatif akan memperlihatkan bagaimana jenis operasi metafora visual yang terjadi.

Pada tahap berikutnya dilakukan analisis semiotika. Analisis semiotika dipilih dalam penelitian ini karena disesuaikan dengan tujuan utamanya yang ingin mengetahui struktur tanda yang terdapat pada komunikasi yang disampaikan iklan Vidisep. Penelitian ini fokus pada bagaimana pesan, atau teks, dibuat agar mampu berinteraksi dengan orang dalam memproduksi suatu makna. Dengan kata lain penelitian ini mengikuti mazhab penelitian studi komunikasi yang memandang komunikasi sebagai produksi dan pertukaran makna (Fiske, 2016).

Dalam semiotika, pesan adalah konstruksi tanda yang menghasilkan makna. Perhatian utamanya adalah teks dan bagaimana teks tersebut dibaca sebagai sebuah proses pengungkapan makna. Pengungkapan makna ini terjadi ketika pembaca berinteraksi dengan teks, dan melibatkan pengalaman kulturalnya untuk menerjemahkan kode dan tanda yang membentuk teks (Fiske, 2016).

Iklan merupakan salah satu bentuk karya komunikasi visual. Sehingga selain fungsi utamanya adalah fungsi komunikasi, iklan juga memiliki fungsi signifikasi (signification), yaitu fungsi dalam menyampaikan sebuah konsep, isi, atau makna. Menurut Yasraf Amir Piliang yang diutarakan dalam kata pengantar buku karya Sumbo Tinarbuko (2010), ada dimensi-dimensi khusus pada sebuah iklan yang membedakannya dari objek-objek seni pada umumnya. Sebuah iklan selalu berisikan unsur-unsur tanda berupa objek yang diiklankan; adanya konteks berupa lingkungan, orang, atau makhluk lainnya yang 
memberikan makna pada objek; serta keberadaan teks (berupa tulisan) yang memperkuat makna, meskipun yang terakhir ini tidak selalu hadir dalam sebuah iklan.

Analisis yang akan dipakai untuk menelaah pemaknaan dalam iklan Vidisep adalah dengan memakai analisis semiotika Roland Barthes. Menurut Barthes (2007), semiotika mempostulasikan suatu hubungan antara dua terma, penanda (signifier) dan petanda (signified). Hubungan ini berkaitan dengan objek-objek yang termasuk ke dalam kategorikategori yang berbeda, dan karena itulah hubungan ini tidak bersifat persamaan (equality) melainkan kesepadanan (equivalence).

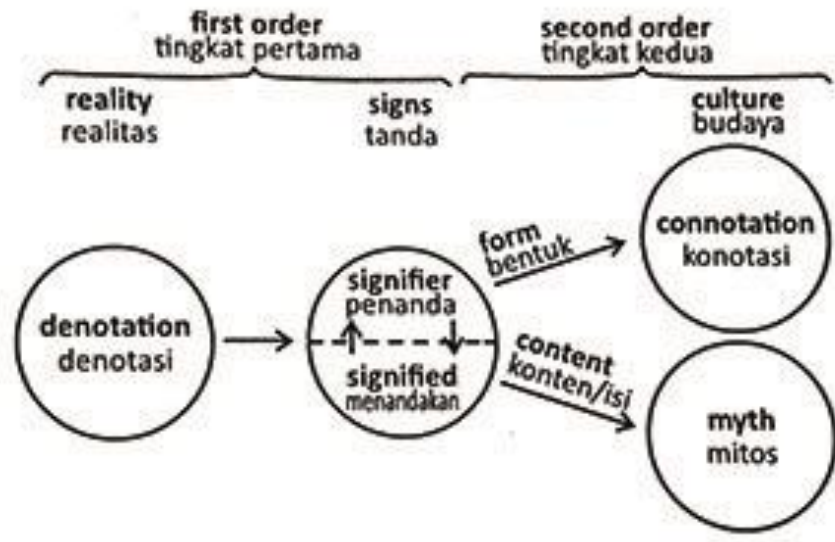

Gambar 1. Skema dua tataran proses signifikansi Barthes Sumber : Buku Pengantar Ilmu Komunikasi

Roland Barthes menunjukkan sebuah doktrin semiotika baru yang memungkinkan para peneliti untuk menganalisa sistem tanda guna membuktikan bagaimana komunikasi nonverbal terbuka terhadap interpretasi melalui makna tambahan atau connotative. Gagasan inti dari teori Barthes adalah gagasan mengenai dua tataran signifikansi, denotasi dan konotasi, serta mitos.

Tataran pertama signifikansi mendeskripsikan hubungan antara penanda dan petanda dalam tanda serta tanda dengan referennya dalam realitas eksternal. Barthes menyebut hal itu sebagai denotasi (Fiske, 2016). Makna denotasi bersifat langsung, yaitu makna khusus 
yang terdapat dalam sebuah tanda, dan pada intinya dapat disebut sebagai gambaran sebuah petanda (Berger, 2005).

Konotasi adalah istilah yang digunakan Barthes untuk mendeskripsikan salah satu dari tiga cara dimana tanda bekerja pada tataran kedua signifikansi. Konotasi mendeskripsikan interaksi yang terjadi ketika tanda bertemu dengan perasaan atau emosi pengguna dan nilai-nilai dari kebudayaan mereka. (Fiske, 2016). Barthes menganggap faktor penting dalam konotasi adalah penanda dalam tataran pertama. Penanda tataran pertama adalah tanda konotasi.

Mitos merupakan cerita atau narasi yang mengekspresikan dan menyimbolkan aspek lapisan dalam eksistensi manusia. Bagi Barthes, mitos adalah cara berpikir sebuah kebudayaan mengenai sesuatu, cara mengkonseptualisasikan atau memahaminya. Mitos bekerja untuk menaturalisasikan sejarah. Mitos bersifat dinamis karena mengalami perubahan dan beberapa mitos bisa berubah dengan cepat agar bisa menyesuaikan diri dengan perubahan kebutuhan dan nilai-nilai dari kebudayaan di mana mitos tersebut menjadi hidup.

\section{PEMBAHASAN}

Vidisep merupakan sebuah merek produk obat antiseptik yang dibuat oleh PT. Kimia Farma Tbk. Sedangkan biro iklan yang membuat iklan ini adalah Hakuhodo Indonesia. Kategori produk yang diikuti iklan Vidisep adalah Health Products and OTC Medicines. Dalam lomba Citra Pariwara tahun 2016, iklan Vidisep yang berjudul Liquid Soldier meraih penghargaan Best of Category untuk kategori media Print \& Print Craft. Hal ini menandakan bahwa iklan cetak Vidisep telah mendapat pengakuan sebagai iklan terbaik dari insan periklanan.

\section{Analisis Visual Iklan}

Iklan media cetak obat antiseptik Vidisep dibuat dengan tata letak yang berorientasi 
portrait. Eksekusi kreatif visualnya memakai teknik fotografi yang telah diolah secara digital. Iklan ini tidak memakai headline dalam visualisasinya, sehingga kekuatan komunikasi melalui gambar terlihat sangat menonjol.

Elemen visual utama iklan Vidisep memperlihatkan sebuah gambar larutan berwarna coklat yang sedang larut dalam air yang bening (Gambar 1). Larutan coklat tersebut merupakan visualisasi dari larutan antiseptik Vidisep. Melalui rekayasa visual yang memakai bantuan komputer grafis, larutan berwarna coklat digabung dengan objek visual lain berupa kumpulan tentara yang siap bertempur. Objek tentara ini diberi warna sesuai warna larutan antiseptik dan dibuat agar terlihat bercampur dengan objek tersebut. Pemakaian background yang polos membuat visualisasi yang terbentuk menjadi semakin jelas.

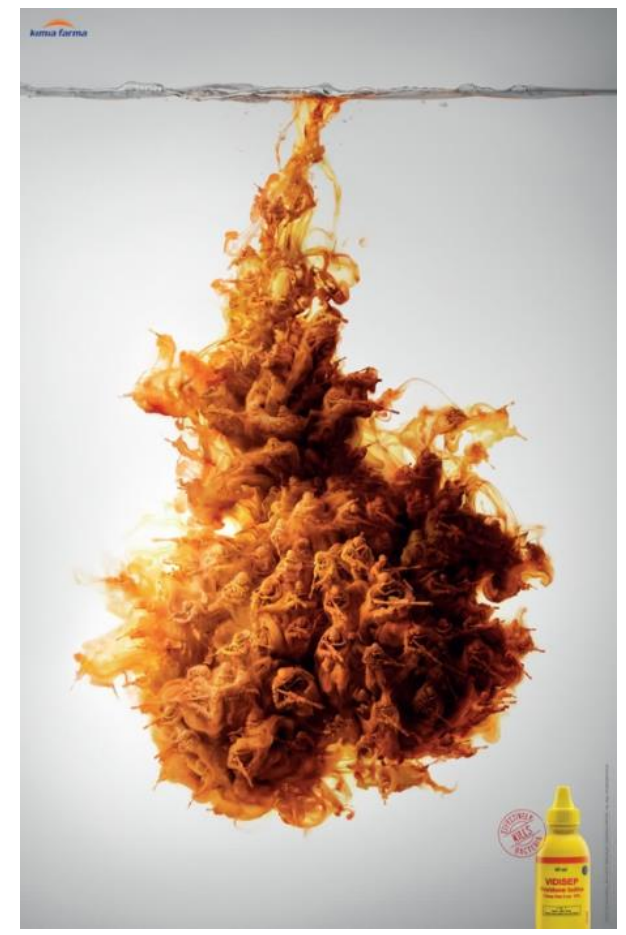

Gambar 2. Iklan media cetak Vidisep Sumber: www.citrapariwara.org

Selain elemen visual utama yang mendominasi tampilan iklan Vidisep, terdapat beberapa elemen visual lainnya yang berukuran lebih kecil. Elemen-elemen tersebut adalah logo 
Kimia Farma sebagai produsen, foto kemasan obat Vidisep, dan cap berbentuk bulat bertuliskan "Effectively kills bacteria". Meskipun berukuran lebih kecil, semua elemen ini bertujuan untuk menguatkan pesan yang coba disampaikan melalui elemen visual utama. Strategi kreatif iklan Vidisep berdasarkan teori Profesor Charles Frazer dari University of Washington termasuk strategi preemtive (Moriarty dkk., 2011). Strategi ini memakai atribut atau manfaat yang lazim terdapat pada produk. Strategi preemtive biasanya digunakan untuk kategori-kategori produk dengan sedikit diferensiasi atau kategori produk baru. Vidisep termasuk dalam kategori obat antiseptik, dimana tidak terdapat diferensiasi yang berbeda jauh dengan para pesaingnya. Iklan Vidisep memakai atribut berupa visualisasi cairan antiseptik yang larut dalam air bening.

Daya tarik iklan merupakan bagian dari strategi kreatif iklan dan dipakai sebagai landasan untuk mempersiapkan suatu pesan iklan. Sehingga daya tarik iklan harus berpegang kepada strategi kreatif yang telah ditetapkan sebelumnya. Daya tarik pada iklan Vidisep dipahami sebagai sesuatu yang mampu membangkitkan ketertarikan konsumen mengenai kebutuhan mereka terhadap obat antiseptik. Sehingga manfaat dari produk menjadi fokus dari pesannya.

Daya tarik iklan Vidisep memakai daya tarik emosional. Menurut Belch dan Belch (2015), daya tarik emosional menggunakan pendekatan yang berhubungan dengan kebutuhan sosial dan psikologis konsumen untuk membeli suatu produk atau jasa. Daya tarik emosional pada iklan Vidisep terkait dengan keselamatan. Konsumen produk antiseptik merupakan orang-orang yang peduli terhadap keselamatan dan kesehatan diri maupun orang sekitarnya.

Eksekusi kreatif iklan digunakan pada berbagai variasi daya tarik iklan. Eksekusi kreatif iklan merupakan suatu cara agar daya tarik dijadikan sebuah pesan yang diperlihatkan kepada 
konsumen (Belch dkk., 2015). Berdasarkan teori Belch dan Belch maka eksekusi kreatif pada iklan Vidisep disajikan secara fantasi (imagery). Eksekusi iklan ini digunakan ketika tujuan dari iklan Vidisep adalah mendorong konsumen untuk mengasosiasikan merek dengan suatu simbol, karakter, atau suatu situasi. Sehingga iklan Vidisep secara tampilan termasuk iklan yang mengedepankan unsur visual seperti ilustrasi, gambar, dan/atau simbol dibandingkan informasi.

\section{Analisis Metafora Visual}

Metafora merupakan salah satu jenis retorika visual yang paling sering dipakai dalam visualisasi sebuah iklan karena cukup atraktif untuk dapat membuat khalayak tertarik. Menurut Kaplan berdasarkan penelitian Leiss dkk. ditemukan bukti dari berbagai riset bahwa pemakaian visual dan teknik metafora mendominasi periklanan modern (Smith dkk., 2005). Kemampuan metafora untuk menampilkan visual yang tidak biasa dalam iklan Vidisep merupakan sebuah kelebihan yang berguna dalam upaya menarik perhatian konsumen.

Analisis untuk melakukan identifikasi metafora visual pada iklan Vidisep dilakukan dengan tahapan-tahapan yang dicetuskan oleh Stuart Kaplan. Analisis dimulai dengan kegiatan memperhatikan kehadiran sebuah metafora dalam iklan. Langkah kedua adalah menunjuk dua syarat dari metafora. Selanjutnya sebagai langkah ketiga yaitu mengidentifikasi sifat yang ditransfer ke produk (Smith dkk., 2005). 


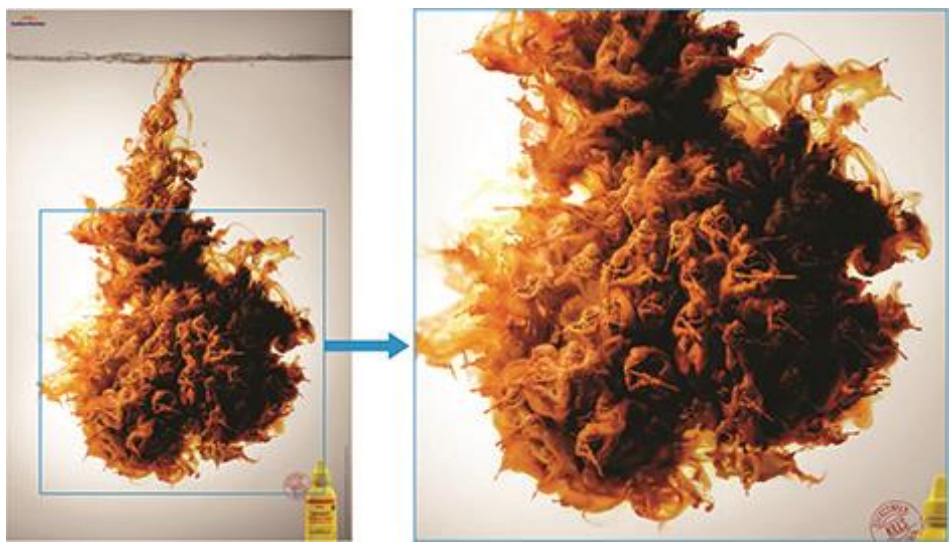

Gambar 3. Metafora pada iklan Vidisep Sumber: pribadi

Salah satu petunjuk akan kehadiran metafora adalah adanya gambar atau elemen gambar yang tampak terdistorsi atau tidak pada tempatnya. Seringkali elemen gambar tersebut merupakan pelanggaran terhadap pemahaman khalayak tentang realitas fisik. Sifat fisik yang terlihat dari satu elemen bergambar dimodifikasi sedemikian rupa melalui berbagai teknik visualisasi. Khalayak kemudian akan mengidentifikasi kedua subjek dalam metafora visual dan mampu menentukan subjek primer (produk yang diiklankan).

Pada gambar 3 terlihat bahwa kehadiran metafora terdapat pada elemen visual utama iklan. Metafora diperlihatkan dengan teknik modifikasi karakteristik fisik. Visualisasi sekumpulan tentara pada bentuk larutan antiseptik merupakan sebuah gambar yang terdistorsi. Sifat fisik larutan antiseptik dalam air dimodifikasi agar membentuk kumpulan tentara siap tempur.

Analisis selanjutnya untuk melakukan identifikasi metafora visual adalah menunjuk keberadaan dua syarat metafora. Kedua syarat itu adalah adanya target dan sumber (source) metafora. Target dalam visual iklan Vidisep adalah subjek dari metafora yaitu larutan antiseptik. Subjek merupakan produk yang ditawarkan kepada konsumen obat antiseptik. Sedangkan yang dimaksud source adalah ide yang digunakan untuk mentransfer makna baru ke target, yaitu sebagai kumpulan tentara. Source dalam iklan Vidisep 
merupakan sebuah ide untuk menjelaskan kelebihan dari produk obat antiseptik tersebut.

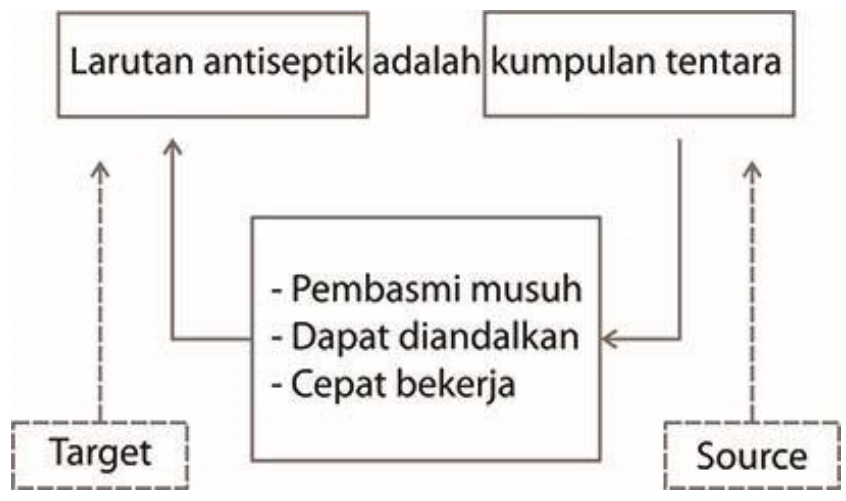

Gambar 4. Dua syarat metafora pada iklan Vidisep Sumber: pribadi

Metafora verbal maupun visual akan melibatkan proses transfer makna dari source ke target. Dalam iklan Vidisep sifat-sifat yang ada pada objek tentara ditransfer ke target yang berupa larutan antiseptik. Pada gambar 4 dapat dilihat bahwa sifat-sifat yang dimiliki source ditransfer ke target yang ternyata memiliki kesamaan saat bekerja. Identifikasi terhadap sifat tentara menunjukkan bahwa ada kesamaan sifat yang berujung pada sebuah pemaknaan yang dimengerti khalayak.

Analisis metafora visual terhadap iklan Vidisep menunjukkan bahwa iklan ini memakai pendekatan retorika visual berupa metafora. Peralihan makna dari satu tanda ke tanda yang lain terjadi dengan cukup jelas. Hal ini akan memudahkan pemahaman oleh khalayaknya. Relasi antara tanda dan makna dalam sebuah karya metafora visual hendaklah tidak terlalu samar dalam penyampaian pesannya (Suprapto, 2018). Iklan Vidisep menunjukkan transfer makna yang terjadi adalah melalui transfer sifat dari kumpulan tentara ke larutan antiseptik. Iklan Vidisep memenuhi ketiga syarat yang dicetuskan oleh Stuart Kaplan agar sebuah iklan termasuk kategori metafora.

\section{Analisis Semiotika Iklan Vidisep}


Analisis semiotika yang dilakukan dalam menelaah struktur tanda pada iklan Vidisep dimulai dengan analisis terhadap pesan linguistiknya. Kemudian dilakukan analisis denotasi dan konotasi yang terdapat pada setiap elemen utama visual iklan, serta analisis terhadap skema naturalisasi mitosnya.

\section{Pesan Linguistik}

Teks merek (logotype) yang ditempatkan sebagai bagian dari logo dan diposisikan di atas dan di bawah logogram Kimia Farma. Logo perusahaan ini diletakkan di sudut kiri atas iklan. Teks merek "Kimia Farma" yang ditempatkan mendampingi logogram bermakna denotasi perusahaan. Teks ini berfungsi menjelaskan nama perusahaan produsen obat antiseptik Vidisep. Makna konotasi logotype Kimia Farma adalah sebagai perusahaan terkemuka dan terpercaya.

Tagline pada iklan Vidisep adalah "Effectively Kills Bacteria". Tagline ditempatkan dekat foto botol plastik obat dan dibuat menyerupai cap. Makna denotasi pada tagline sesuai dengan apa yang dapat terbaca (secara literal). Makna denotasi yang ada pada teks ini berkaitan dengan keunggulan dan fungsi dari obat antiseptik Vidisep. Makna konotasi yang ingin dibangun adalah sebagai obat yang efektif untuk membunuh semua bakteri, meskipun sebenarnya hal ini tidaklah mungkin.

Sedangkan pada sisi kanan bawah dengan posisi vertikal terdapat tulisan "Baca Aturan Pakai-Jika Sakit Berlanjut Hubungi Dokter". Tulisan ini merupakan sebuah spot peringatan yang diwajibkan pemerintah Indonesia untuk dicantumkan pada iklan produk obat-obatan. Makna denotasi pada tulisan ini dimaksudkan agar konsumen yang menderika gangguan kesehatan untuk menghubungi dokter, jika sakit yang dialaminya belum kunjung sembuh walaupun telah memakai obat ini sesuai aturan pakai. Makna konotasi dari tulisan ini adalah peringatan agar konsumen menyadari obat ini tidak bisa dipakai sembarangan. Selain itu 
memberitahu konsumen bahwa obat ini tidak bisa menjamin kesembuhan bagi setiap konsumennya.

Tulisan lain yang ada pada iklan adalah nama merek obat antiseptik "Vidisep" yang tercantum pada kemasan botol plastiknya. Selain itu terdapat tulisan-tulisan lain yang menginformasikan volume obat yang terdapat dalam kemasan dan kandungan yang dimilikinya. Semua tulisan ini memiliki makna denotatif, karena fungsinya yang bersifat memberitahukan informasi mengenai obat pada konsumen. Sehingga penggunaan tulisan yang bermakna konotatif akan dihindari dalam konteks ini.

\section{Pesan Denotasi dan Konotasi}

Tabel 1. Skema Analisis Pesan Denotasi dan Konotasi

\begin{tabular}{|c|c|c|c|}
\hline No & Gambar & Tanda Denotatif & Tanda Konotatif \\
\hline 1 & & $\begin{array}{l}\text { Larutan berwarna coklat } \\
\text { yang baru larut dalam air } \\
\text { bening. }\end{array}$ & $\begin{array}{l}\text { Larutan antiseptik yang } \\
\text { siap untuk dipakai }\end{array}$ \\
\hline 2 & & $\begin{array}{l}\text { Beberapa orang seperti } \\
\text { tentara berwarna coklat } \\
\text { sedang memegang } \\
\text { senjata dan siap } \\
\text { bertempur }\end{array}$ & Siap membasmi musuh \\
\hline
\end{tabular}




\begin{tabular}{|l|l|l|l|}
\hline 3 & $\begin{array}{l}\text { Batas permukaan air yang } \\
\text { bening dengan udara }\end{array}$ & Air bening yang bersih \\
\hline 4 & $\begin{array}{l}\text { Botol plastik tertutup } \\
\text { berwarna kuning dan } \\
\text { bertuliskan Vidisep } \\
\text { berwarna merah serta } \\
\text { berbagai tulisan lainnya } \\
\text { dipermukaannya. }\end{array}$ & $\begin{array}{l}\text { Obat antiseptik Vidisep } \\
\text { mampu membunuh } \\
\text { bakteri secara efektif }\end{array}$ \\
\hline
\end{tabular}

Sumber : Hasil Karya Penulis, 2020

Analisis terhadap pesan denotasi yang terdapat pada setiap objek dalam iklan Vidisep menunjukkan suatu keterkaitan. Keterkaitan ini berhubungan dengan upaya membangun pesan iklan kepada khalayaknya. Setiap objek dalam iklan memiliki pesan konotasi yang merupakan hasil dari upaya pemaknaan tanda denotasinya.

\section{Analisis Makna Secara Keseluruhan}

Tabel 2. Skema Analisis Makna Keseluruhan

\begin{tabular}{|l|l|l|l|}
\hline No & Gambar & Tanda Denotatif & Tanda Konotatif \\
\hline
\end{tabular}


Riki Himawan, Agung Budi Waspada

Metafora Visual pada Iklan Obat Antiseptik Vidisep, Kajian Semiotika

\begin{tabular}{|c|c|c|}
\hline 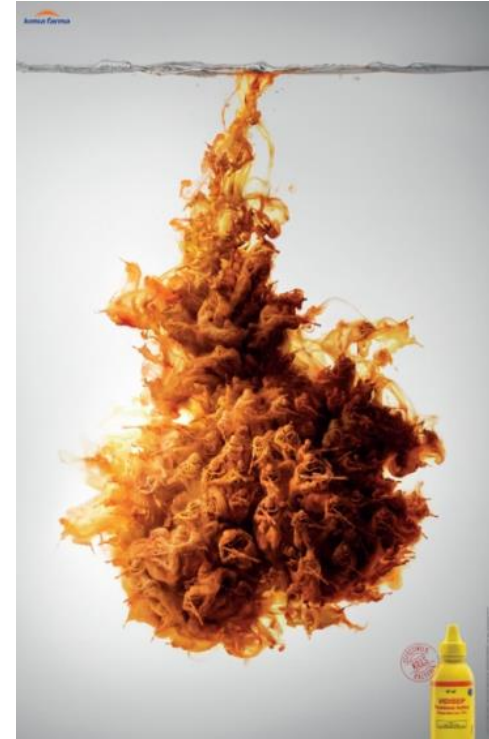 & $\begin{array}{l}\text { Sebuah larutan } \\
\text { berwarna coklat yang } \\
\text { baru larut dalam air } \\
\text { bening. Larutan tersebut } \\
\text { berbentuk sekumpulan } \\
\text { tentara berwarna coklat } \\
\text { sedang memegang } \\
\text { senjata dan siap } \\
\text { bertempur. Pada bagian } \\
\text { kanan bawah terdapat } \\
\text { botol kemasan obat } \\
\text { antiseptik Vidisep yang } \\
\text { diberi cap. }\end{array}$ & $\begin{array}{l}\text { Larutan antiseptik } \\
\text { Vidisep adalah larutan } \\
\text { yang efektif untuk } \\
\text { membasmi bakteri. }\end{array}$ \\
\hline
\end{tabular}

Sumber: Hasil Karya Penulis, 2020

Iklan Vidisep merupakan sebuah iklan yang memakai metafora visual dalam visualisasi utamanya. Hal ini mengartikan pentingnya ketepatan pemilihan objek dalam iklan agar mampu menyampaikan pesan melalui tanda-tanda denotatifnya, sehingga proses transfer makna berjalan dengan mulus. Tanda konotatif yang timbul merupakan sebuah pesan persuasif yang memperlihatkan kelebihan dari larutan antiseptik Vidisep.

Berdasarkan hasil analisis di atas, maka dapat dikatakan iklan Vidisep mencoba untuk memperkuat mitos mengenai fungsi dari obatnya, yaitu sebagai larutan antiseptik. Makna konotatif yang terbentuk dari berbagai elemen visual pada iklan tersebut adalah larutan antiseptik Vidisep adalah larutan yang efektif untuk membasmi bakteri. Makna ini membentuk sebuah mitos yang kemudian ternaturalisasi menjadi sebuah realitas. Realitas yang terbentuk adalah sebagai larutan antiseptik ampuh dalam membasmi bakteri.

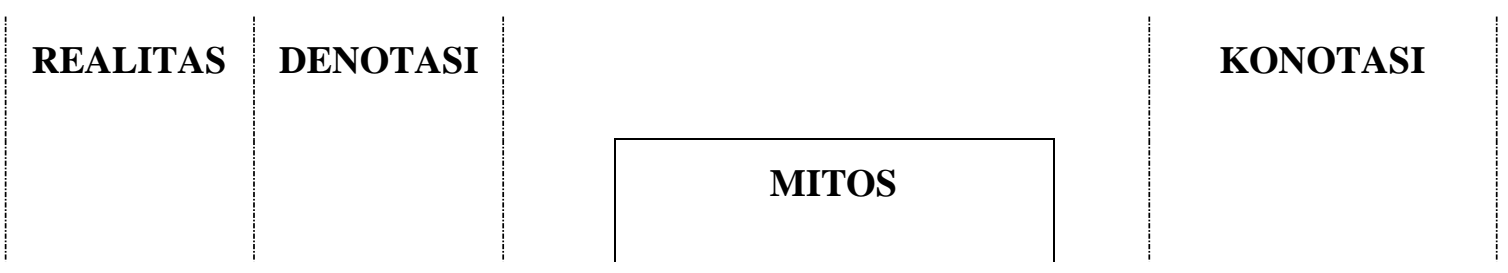




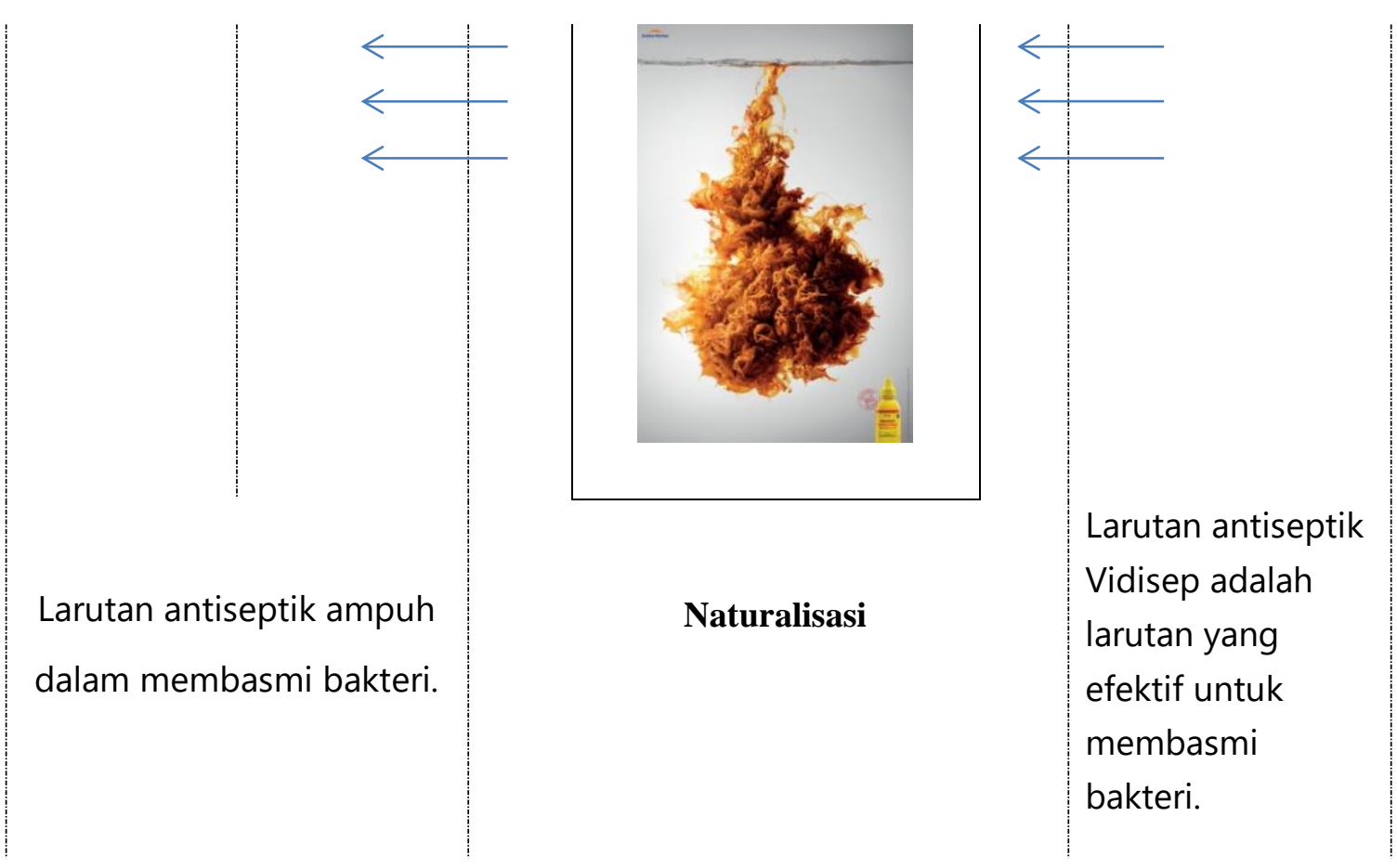

Gambar 5. Skema Naturalisasi Mitos

Sumber : Hasil Karya Penulis, 2020

Realitas yang terbentuk pada iklan sesuai dengan fungsi dari obat antiseptik. Antiseptik adalah produk biosidal untuk menghancurkan atau menghambat pertumbuhan mikroorganisme yang terdapat di dalam atau pada jaringan hidup, misalnya kulit (McDonnell, 2017). Atau dengan kata lain sebagai cairan obat luar yang digunakan sebagai antiseptik untuk membunuh maupun menghambat pertumbuhan bakteri pada permukaan kulit.

Obat antiseptik Vidisep merupakan larutan antiseptik yang mengandung zat aktif Povidone iodine sebanyak 10\%. Povidone iodine telah digunakan secara luas untuk antiseptik kulit. Secara umum, Povidone iodine adalah salah satu dari sedikit antimikroba topikal yang terbukti efektif melawan bakteri, beberapa virus, jamur, spora, protozoa, dan kista amuba. (Bigliardi dkk., 2017). Sehingga dapat disimpulkan bahwa kandungan zat aktif pada Vidisep 
merupakan senyawa yang telah diakui efektivitasnya dalam membasmi bakteri.

Eksekusi visual iklan Vidisep disajikan secara fantasi. Melalui penggunaan digital imaging, iklan Vidisep memakai pendekatan metafora visual untuk mewujudkan visualisasi karakteristik zat aktif pada larutan antiseptiknya. Eksekusi yang dilakukan dengan seksama menghasilkan sebuah visualisasi iklan yang menarik perhatian.

Penyimpangan berseni (artful deviation) yang menjadi syarat adanya retorika visual sangat terasa hadir pada visualisasi utama iklan. Menurut McQuarrie dan Mick, salah satu kontribusi kunci dari perspektif retorika untuk periklanan adalah gagasan tentang sosok retorik, yang dapat didefinisikan sebagai penyimpangan yang berseni (Scott dkk., 2003). Seperti semua fenomena estetika, figur retoris pada iklan Vidisep memiliki potensi untuk memberikan kesenangan.

Iklan Vidisep adalah sebuah contoh bentuk penyimpangan berseni (artful deviation). Elemen visual utama iklan Vidisep memperlihatkan visualisasi cairan obat yang sedang larut dalam air. Penyimpangan yang terjadi adalah larutan tersebut berbentuk sekelompok pasukan dengan senjata yang siap bertempur. Visualisasi tentara berbaur dengan visualisasi larutan antiseptik dan berwarna sama dengan warna larutan. Sehingga bila dilihat sekilas, visualisasi tentara tidak akan terlihat dengan jelas. Penggunaan teknologi komputer grafis membuat visualisasi penyimpangan ini terlihat seolah nyata.

Visualisasi tentara pada iklan Vidisep adalah sebagai source dalam proses transfer makna metafora visualnya. Makna yang ditransfer adalah karakteristik cara kerja obat antiseptik yang mengandung senyawa Povidone iodine. Karakteristik senyawa yang efektif dalam membunuh bakteri dibandingkan dengan karakteristik tentara saat bertempur. Sehingga terbentuklah konotasi bahwa larutan antiseptik Vidisep adalah larutan yang efektif untuk membasmi bakteri. 


\section{PENUTUP}

Iklan cetak obat antibiotik Vidisep merupakan sebuah iklan yang memakai pendekatan metafora visual dalam upayanya untuk melakukan persuasi terhadap khalayak. Analisis dengan teori Stuart Kaplan menunjukkan bahwa iklan ini memenuhi semua syarat sebagai sebuah karya metafora visual. Penggunaan teknik digital imaging dalam membuat visualisasi metaforanya menjadikan iklan ini mengedepankan tanda-tanda visual untuk berkomunikasi. Visualisasi utama dalam iklan menunjukkan penyimpangan berseni (artful deviation) sebagai tanda keberadaan retorika visual. Penyimpangan berseni merupakan bagian penting yang akan membuat sebuah karya yang memakai retorika visual bisa dinikmati dan disukai oleh khalayak.

Hasil analisis semiotika Roland Barthes pada iklan ini menunjukkan adanya penggunaan bahasa tanda yang menimbulkan konotasi larutan antiseptik Vidisep efektif untuk membasmi bakteri. Pemaknaan terhadap objek-objek visual pada iklan memiliki relasi dengan karakteristik dari larutan antiseptik Vidisep. Terdapat kesamaan sifat antara senyawa utama obat antiseptik yang bernama Povidone iodine dengan sifat yang terdapat visual tentara. Kemampuan senyawa utama obat yang efektif membunuh bakteri dibandingkan dengan kemampuan tentara dalam membunuh atau membasmi musuh. Konotasi ini menjadi sebuah mitos yang kemudian menjadi sebuah realitas baru dan dipercaya oleh khalayak bahwa larutan antiseptik ampuh dalam membasmi bakteri.

\section{DAFTAR PUSTAKA}

\section{Acuan dari buku:}

Barthes, Roland (2007): Membedah Mitos-mitos Budaya Massa: Semiotika atau Sosiologi Tanda, Simbol, dan Representasi, Jalasutra, Yogyakarta. 
Belch, G.E. \& Belch, M.A. (2015). Advertising and Promotion: An Integrated Marketing Communications Perspective. Singapore: McGraw-Hill Education.

Berger, Arthur Asa (2005): Tanda-tanda dalam Kebudayaan Kontemporer, Suatu Pengantar Semiotika, Tiara Wacana, Yogyakarta.

Bigliardi, P. L., Alsagoff, S., El-Kafrawi, H. Y., Pyon, J. K., Wa, C., \& Villa, M. A. (2017). Povidone iodine in wound healing: A review of current concepts and practices. International journal of surgery (London, England), 44, 260-268. https://doi.org/10.1016/j.ijsu.2017.06.073

Fiske, John (2016): Pengantar Ilmu Komunikasi, Buku Litera, Yogyakarta.

Forceville, C (2002). Pictorial Metaphor in Advertising. New York: Routledge.

Kotler, P., Armstrong, G., \& Opresnik, M.O. (2018). Principles of Marketing. Harlow: Pearson Education Limited.

Nurusholih, S. (2019). Analisis Retorika Visual Konten Iklan Produk Pada Account Instagram Bank BNI. Desain Komunikasi Visual, Manajemen Desain Dan Periklanan. Demandia. 4(2), 199-214. doi:10.25124/demandia.v4i2.1935

Moriarty, S., Mitchell, N., \& Wells, W. (2011). Advertising. Jakarta: Kencana.

Moriarty, S., Mitchell, N., \& Wells, W. (2015). Advertising \& IMC: Principle and Practice. Harlow: Pearson Education Limited.

Morissan (2010). Periklanan: Komunikasi Pemasaran Terpadu. Jakarta: Kencana.

Scott, L.M. \& Batra, R. (2003). Persuasive Imagery: A Consumer Response Perspective. New Jersey: Lawrence Erlbaum Associates, Inc.

Smith, K., Moriarty, S., Barbatsis, G., \& Kenney, K. (2005). Handbook of Visual Communication : Theory, Methods, and Media. Oxfordshire: Routledge.

Suprapto, R. (2018). Pendekatan MetaforaVisual Dalam Gaya Pesan Iklan Televisi Unique $\begin{array}{llll}\text { Selling } \quad \text { Proposition. } & \text { 24-37). }\end{array}$ https://doi.org/10.36262/widyakala.v5i1.99

Tinarbuko, Sumbo (2010): Semiotika Komunikasi Visual, Jalasutra, Yogyakarta.

\section{Acuan dari dokumen online:}


Serat Rupa Journal of Design, January 2021, Vol.5, No.1: 19 - 33

E-ISSN: 2477-586X, ISSN: 2338-3348 | https://doi.org/10.28932/srjd.v5i1.2951 | Received: 29- 10- 2020, Accepted: 14- 012020

Riki Himawan, Agung Budi Waspada

Metafora Visual pada Iklan Obat Antiseptik Vidisep, Kajian Semiotika

Data dan karya pemenang Citra Pariwara 2016, Diunduh 14 Mei 2019 dari http://archive.citrapariwara.org/penghargaan/2016/print?resul 
